\title{
The emerging economy of Vietnam: Pitfalls, problems and the relevance of business education
}

Quan- Hoang Vuong

August 6, 2013

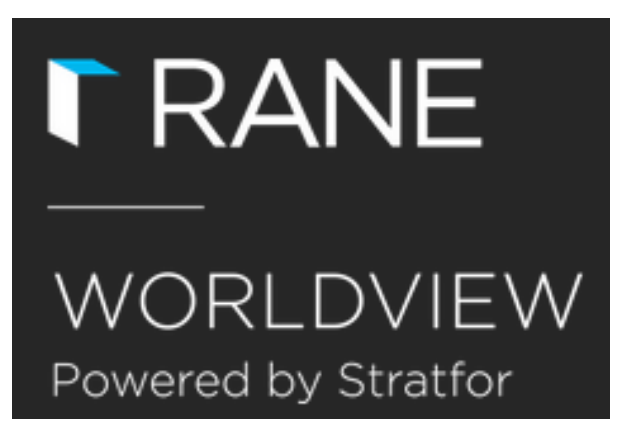

Stratfor Worldview

https:/ / worldview.stratfor.com/ article/ emerging- economy- vietnam- pitfallsproblems- and-relevance- business- education 


\section{The emerging economy of Vietnam: Pitfalls, problems and the relevance of business education}

a Quality Insights on Vietnam's Economy and Business lly and Time-Saving Tool For Your Making Well Informec

Like many emerging economies, Vietnam's economy has undergone major shifts for a quarter of a century. On the one hand, this period is very short compared to the history of the capitalism and the market economy in Western - now mostly developed - countries. On the other hand, 25 years is long enough for many important changes to have taken place in Vietnam's once war-stricken economy.

The current time period is a crucial turning point for Vietnam. At present, policy-makers and economists see mounting pressures on Vietnam's economy and tend to agree that it demands a renewed tide of 
reform to survive stormy years ahead, especially after recent years of high inflation, lower economic efficiency and risks of losing steam.

Since business activities have and will contribute to most economic achievements in Vietnam over the reform period, it makes sense to review the roles, impacts and lessons from actual happenings in Vietnam's business education sector, which we believe have had profound effects on not only the corporate sector, but also on political circles, various communities and ordinary Vietnamese households. In addition, these trends have and will continue to influence the type of management education that Vietnam offers.

Several problems have emerged over recent years in Vietnam that illustrate the relative lack of strong business knowledge and, in turn, a lack of business education.

\section{Illusion of prosperity}

The growing economy and expansion of the business sector gave many Vietnamese - and some foreigners who watch the Vietnamese economy an illusion of prosperity, especially in the booming years of the local stock markets, 2006-2007. One result, perhaps unexpected, is a level of wealth (unreal, in some cases), revealed by what people buy: lands, luxury apartments and villas, Hermes and Louis Vuitton bags, luxury cars, private jets and helicopters. The kickoff started with the purchase of a $\$ 7$ million private jet by the head of Hoang Anh Gia Lai; in 2008, other rich men in Vietnam started buying private jets.

Some might argue that the "illusion" of prosperity happened almost by accident, because of the runaway boom rather than from any systematic or knowledge based practice. 
Macro instability and structural problems

Vietnam's macro economy appeared relatively stable in the 1997-2006 period, with low inflation, a higher pace of total output expansion - for instance, 7 to 9 percent annual growth - and a moderate level of trade deficit. This is not the say that the economy was in perfect condition in this period. In fact, Vietnam could not weather the adverse impact from the 1997-98 Asian financial turmoil, which partly curbed the FDI flow into its economy. Nonetheless, in general, economic progress and fast-growing output have been plausible.

Starting in late 2006, both public and private sector firms began to experience structural problems, rising inefficiency, and waste of resources. First, the daunting problem of inflation recurred, quickly growing out of control in mid-2008 and peaking at an annualized 23\% level for that year. Interestingly, it started rising in Vietnam before the financial crisis hit the global economy in full force. Higher inflation in Vietnam has been long considered a consequence of long-standing structural problems nested inside the economy: misallocation of resources, ownership structure, inefficient public spending, local creditfueled growth, and similar factors.

Again, likely because of a lack of business education, very few business leaders were able to identify these problems, or paid attention to them once they began to happen, before the whole economy plummeted in late 2008. They tended to pursue business practices and management styles that had worked before, yielded rising stock prices, cash surpluses from sales of shares, or abnormal profits from property-based rent-seeking. But when the economy dropped, those business practices became useless. Vuong et al. argued that numerous business owners considered 
selling equity stake of their businesses an exit strategy or entered mergers and acquisitions while assuming all would work out well for their entrepreneurial endeavors.[1]

Acute questions on capability of competing locally and globally

Trade deficit has been a persistent problem for the Vietnamese economy. This gives rise to the question of the local business sector's capability to compete not only internationally but also locally. In fact, Vietnamese goods appeal to advanced economies, including Vietnam's major importers, such as the US, European countries, and Japan, because local firms tend to supply low-cost agricultural and aquatic products, in addition to textiles, footwear, furniture, or industrial goods, such as LCDs or electric cables. Unfortunately, Vietnamese firms increasingly compete - on their own territory - with Chinese manufacturers and exporters. On the one hand, Chinese firms consume a large portion of agricultural produces cultivated in Vietnam, ranging from cassava and rice, to coffee and shrimp, for instance, as well as natural resources such as iron ore, coal, bauxite, and rubber latex. On the other hand, Chinese goods flood local Vietnamese markets in both urban and rural area markets. The goods range from low-value items such as cheap clothes, footwear, tropical fruits and vegetables, and agricultural products to higher-valued technology goods such as air-conditioners, motorbikes, mobile phones, or tablet PCs. Thus, the pressure is rising with more regional players joining the battle for local markets. However, the local Vietnamese business community simply ignores the game, as if they have never learned the lesson of cost-benefit analysis or competition, which again, could be a possible result of the lack of widespread business education.

Hello "pharaohs" of financial pyramids, bye-bye hard-working 
entrepreneurs

Recently, Vietnam has become increasingly a victim of severe financial fraud. Since, 2005, about 200 cases of financial fraud have emerged. Most have stemmed from (i) high-interest money games; (ii) risky equity speculation; (iii) risky real property speculation; and, (iv) other forms of purchasing of highly speculative financial/physical assets, such as online foreign exchange accounts, gold trading or multi-level marketing system expansion. For instance, in early October 2011, the Vietnamese securities market uncovered a huge pyramid scheme, estimated to be at least $\$ 190$ million. The presumably well-educated, experienced, and wellestablished investors who were deceived - including commercial banks and securities companies - were apparently driven by greed for easy money. The instigators are called "Pharaohs," because they built the "pyramids" that toppled so many investors.

Given the fact that most of the country's businesses were struggling with financial distress and the credit crunch as the prevailing lending interest rates in the formal banking sector varied from 20 to $25 \%$ per annum, loan sharks offered interest rates from 60 to $90 \%$ p.a. Limited access to finance and contracted liquidity gave rise to the problem of "financial pyramids," where many layers of small lenders borrowed money to lend onward to "someone who pays a higher interest rate" than the rate at which they borrow.

It is impossible to explain why banks and other firms - veteran financial professionals - were so easily taken advantage of by such traditional and typical ponzi traps. Despite the Vietnamese media's exposure of lessons from the Bernie Madoff scandal, such pyramids hurt thousands of investors, who perhaps suffered "short-term memory loss." They may 
have "learned" the lesson from the Madoff scandal, but still made the same mistake themselves.

Old mind, new game and why business education matters?

The world has changed substantially since the 2008-09 crisis. But Vietnamese business firms have not adapted fully. In fact, there is evidence of them taking a few steps "back" to the old mentality, looking very much like a centrally planned economy. First, when the stock market plummeted in the 2008-2011 period, there was an increasingly loud voice from the private-sector firms urging the government to step in and save failing firms and investors. On March 5, 2008, about 100 investors gathered in front of the State Securities Commission to call upon the government watchdog to prevent stock prices from dropping. Despite the fact that Deputy Prime Minister Nguyen Sinh Hung - who used to be Finance Minister and now is Chairman of the National Assembly - had officially stated that the stock market reached its bottom on March 6, 2008, it continued to fall.[2] Second, in difficult times, many firms believe their way out of the situation "naturally" depends on subsidies from the government. Third, domestic firms have even formed an alliance in building barriers to new entrants or to block non-allied competitors.

Such economic and business problems reveal that standard aspects of business education have not been either observed or implemented within the business sector of Vietnam. The issues mentioned so far involve such elements as management knowledge, business operation principles, costbenefit analysis, analytical skills, leadership's vision, medium- to longerterm strategies, and business ethics, few of which seem evident. Weak management, technical and conceptual skills have led to more problems than business managers had previously thought, since it turns out that 
fixing a business issue in a chaotic macro-economic setting could easily cause a poor-performing firm to collapse.

This only strengthens our argument for the promotion of quality business education, not only for times of crisis but also to help mitigate the risks of worse crises in the future.

[1] Vuong, Q.H., T.D. Tran, and T.C.H. Nguyen (2010) "Mergers and acquisitions market in Vietnam's transition economy,” The Journal of Economic Policy and Research, 5(1): 1-54.

[2] Vuong, Q. H. and M.C. Pham (2009) Kinh te Viet Nam: Thang tram va Dot Pha. Hanoi: National Political Publishing House.

This passage is an excerpt from the following book, which can be found here: Vuong, Q. H., Tran, T. D., Napier, N. K., \& Dau, T. H. (2013). Business Education in the Emerging Economy of Vietnam: Twenty Years of Expectations, Illusions, and Lessons. In Innovation in Business Education in Emerging Markets, edited by Ilan Alon, Victoria Jones and John R.

\section{Keep Reading: \\ Create an account to get 3 free articles}

FIRST NAME*

EMAIL*

PHONE
LAST NAME*

PASSWORD*

JOB TITLE 


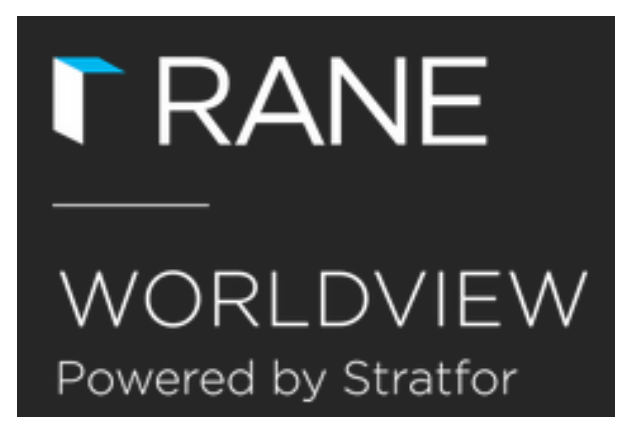

\section{Stratfor Worldview}

https:// worldview.stratfor.com/article/ emerging- economy- vietnam- pitfallsproblems- and-relevance- business- education 